\title{
Primary lymphoma of the colon: report of two cases and review of literature
}

\author{
Manoj Pandey ${ }^{1 *}$ (D), Jyoti Swain ${ }^{1}$, Hema Malini lyer ${ }^{2,3}$ and Mridula Shukla ${ }^{4}$
}

\begin{abstract}
Background: Gastrointestinal tract is the most frequent site of extranodal lymphoma accounting for approximately $40 \%$ of all extranodal lymphomas; out of these, non-Hodgkin's lymphoma (NHL) comprises $4 \%$ of total cases. Primary lymphoma arising in the colon is very rare comprising only $0.2-1 \%$ of all colonic malignancy.

Patients and methods: We report two cases of 13- and 20-year-old boys with NHL of colon presenting with abdominal pain and weight loss and discuss the approach to colonic lymphoma after a review of world literature to provide an overview on colonic lymphoma.

Results: Colonic NHL most commonly affects older age group with mean age of diagnosis being 55 years. Abdominal pain and weight loss are the two most common presentations with palpable abdominal mass as physical examination finding in half of the cases.

Conclusions: Colonic lymphoma in young adolescence is rare. Multimodality approach involving both surgery and chemotherapy is the principal mode of treatment. Radiotherapy is used in selected cases. If diagnosed preoperatively, non-surgical management can be attempted.
\end{abstract}

Keywords: Lymphoma, Extranodal, Colon, Surgery, Chemotherapy, CD20, Immunohistohemistry

\section{Background}

Primary colonic lymphoma is a rare entity comprising about $0.2-1 \%$ of all colonic malignancies [1-4]. NonHodgkin's lymphoma (NHL) is the most common histological subtype. Males are most commonly affected with peak incidence in sixth and seventh decade of life [5]. Though lymphoma is common in children, extranodal primary colonic lymphoma is rare in childhood [6]. We report here two cases of colonic lymphoma in adolescent boys with a review of world literature.

\section{Case report}

\section{Case 1}

A 13-year-old child presented with complaints of dull aching pain in the right lower abdomen since 3 months and lump in the right lower abdomen for 2 months. He also complained of intermittent vomiting with normal bladder and bowel habit. There was no associated fever and melena. Except for the presence of pallor, the general

\footnotetext{
* Correspondence: manojpandey@wjso.com; manojpandey66@gmail.com ${ }^{1}$ Department of Surgical Oncology, Institute of Medical Sciences, Banaras Hindu University, Varanasi 221 005, India

Full list of author information is available at the end of the article
}

physical examination was normal. Abdominal examination revealed tender, hard $10 \times 6-\mathrm{cm}$ mass in the right iliac fossa extending to the midline. The mass had restricted intrinsic mobility, and it did not move with respiration. There was no organomegaly or any other findings on abdominal examination and digital rectal examination. Routine haematological and biochemical investigations were within normal limit except the haemoglobin of $8 \mathrm{~g} / \mathrm{dL}$. There was no occult blood in stool, and chest X-ray was normal. Ultrasonography of the abdomen revealed a large $10.2 \mathrm{~cm} \times 6.73-\mathrm{cm}$ hypoechoic area with anechoic component surrounded by gut loops and omentum in the right iliac fossa. Contrastenhanced computed tomography scan of the abdomen revealed gross circumferential wall thickening of caecum and ascending colon with partial luminal obliteration. The average radial wall thickness was $4.3 \mathrm{~cm}$, and the approximate length of thickened segment was about $10.8 \mathrm{~cm}$ (Fig. 1). Few mesenteric lymph nodes were seen in the right iliac fossa with largest one measuring $39 \mathrm{~mm} \times 42 \mathrm{~mm}$.

(c) The Author(s). 2019 Open Access This article is distributed under the terms of the Creative Commons Attribution 4.0 International License (http://creativecommons.org/licenses/by/4.0/), which permits unrestricted use, distribution, and reproduction in any medium, provided you give appropriate credit to the original author(s) and the source, provide a link to the Creative Commons license, and indicate if changes were made. The Creative Commons Public Domain Dedication waiver (http://creativecommons.org/publicdomain/zero/1.0/) applies to the data made available in this article, unless otherwise stated. 


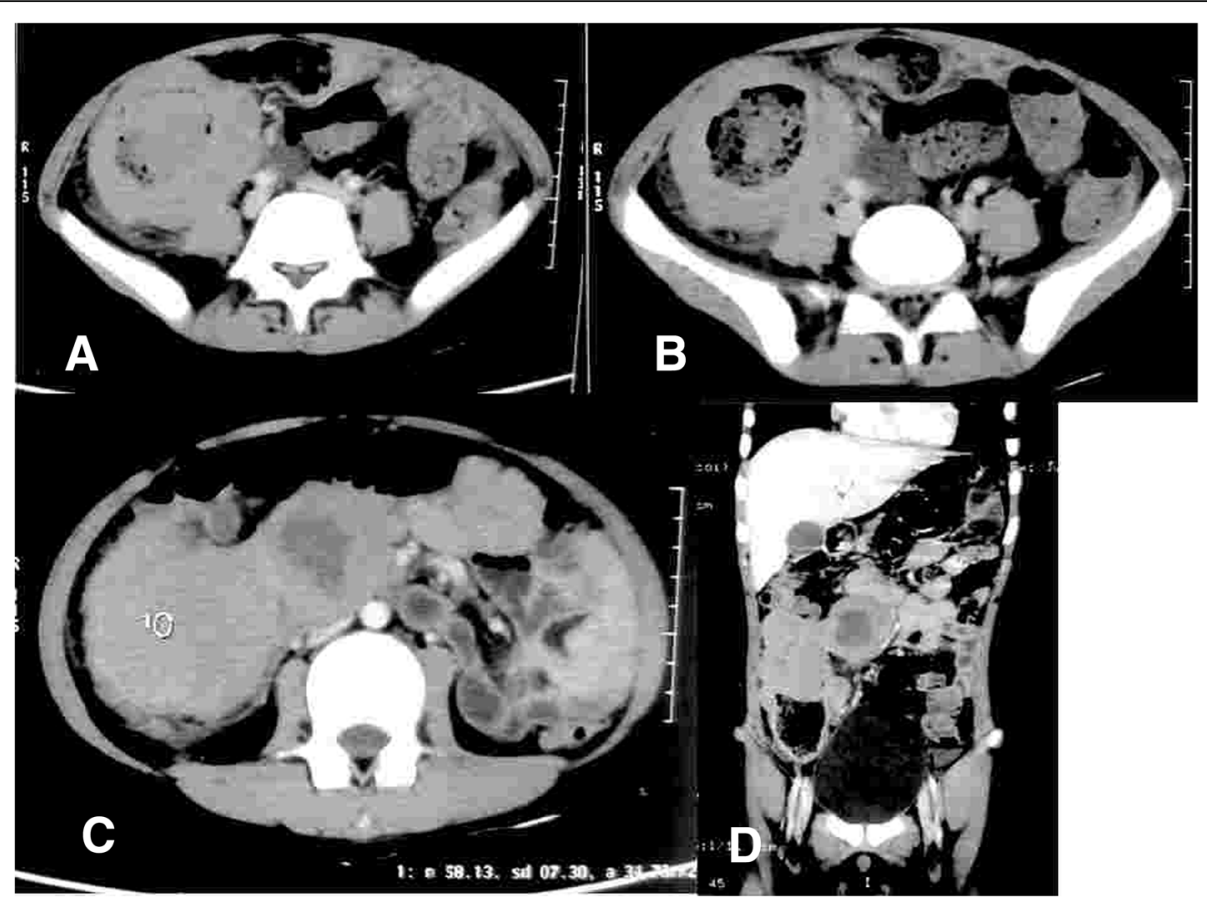

Fig. 1 Computed tomography showing a) the lesion in the caecum, b) lesion in caecum with lymph nodes $\mathbf{c}$ ) ascending colon and $\mathbf{d}$ ) reaching up to transverse colon

A colonoscopy was performed that revealed ulceroproliferative mass in caecum extending up to ascending colon and a biopsy was taken. Histopathological examination of the biopsy revealed mucosal ulceration and necrosis with lamina propria showing sheets of monomorphic round cells having vesicular nuclei with distinct nucleoli which are strongly suggestive of nonHodgkin's lymphoma (Fig. 2). Immunohistochemistry showed CD20 and CD45 positivity while CD3 and cytokeratin were negative (Fig. 2). With the diagnosis of diffuse large B-cell lymphoma (DLBCL), the patient was started on R-CHOP (rituximab, cyclophosphamide, vincristine, and prednisolone). The patient is now doing well and is on regular follow-up.

\section{Case 2}

A 20-year-old boy presented with complaints of altered bowel habits and abdominal pain of 6 months duration. The general physical examination and abdominal examination including digital rectal examination were normal. Haematological and biochemical parameters were remarkable, and there was no occult blood in faeces.

A CT scan was carried out that showed a mass in the pelvis arising from rectosigmoid junction; the planes with the bladder were well maintained, and there was no lymphadenopathy or liver/splenic lesions (Fig. 3). The patient underwent a colonoscopic examination that showed a proliferative growth in the upper rectum and rectosigmoid junction about $15 \mathrm{~cm}$ from anal verge. A biopsy was taken that revealed it to be lymphoma. Immunohistochemistry was performed, and tumour cells were positive for $\mathrm{CD} 20$ and $\mathrm{CD} 45$ while $\mathrm{CD} 3$ was negative (Fig. 4). A diagnosis of diffuse large B cell lymphoma was made.

Patient was started on R-CHOP chemotherapy and had a complete response. Patient is on regular follow-up and is disease-free after 2 years.

\section{Discussion}

Gastrointestinal lymphoma accounts for $5-10 \%$ of all non-Hodgkin's lymphoma with intestinal lymphoma contributing $15-20 \%$ of all gastrointestinal lymphoma [1]. Majority of these arise in the stomach (up to 65\% of all GI lymphoma) followed by the small bowel (20$30 \%)$ with rest arising in the colon and rectum $[1-3,5]$. B cell lymphoma of the colon is the third commonest malignancy of the colon after carcinoma and carcinoid though its incidence is less than $0.5 \%$. Primary gastrointestinal malignancies are very rare in children with non-Hodgkin's lymphoma being the most common [7]. Within the colon, the involvement of caecum is the commonest, and Gonzalez et al. [5] found caecum $(60 \%)$ to be the commonest site, followed by the right (27\%) and the sigmoid colon (13\%). Bairey et al. [3] in their case series of 17 patients also found ileocaecal region to be the most common site of colonic lymphoma accounting for $76 \%$ of cases. In our case reports, the 


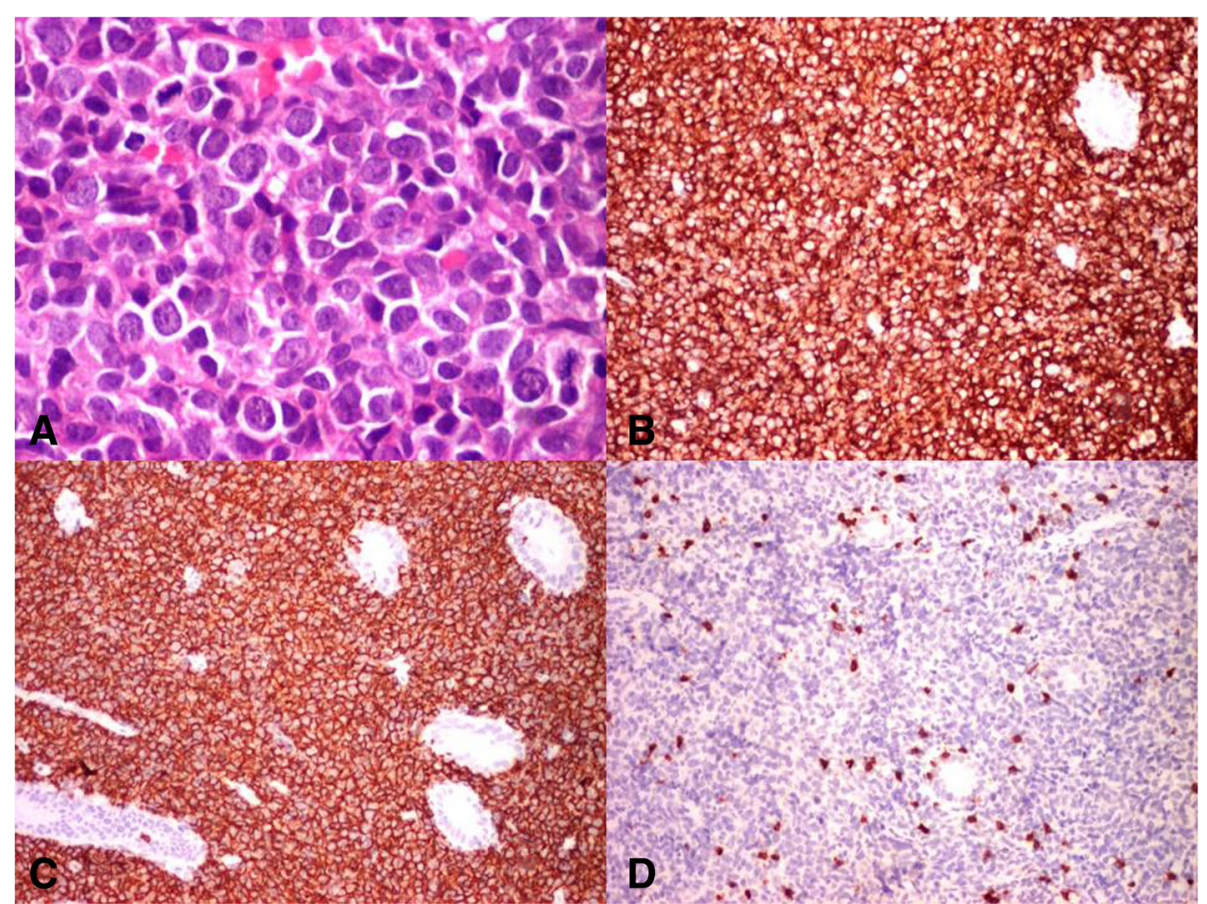

Fig. 2 Photomicrograph showing a non-Hodgkin's lymphoma H\&E $\times 40$, b diffuse CD45 positivity, c CD20 positivity, and $\mathbf{d}$ negative for CD3

site of involvement was also caecum and ascending colon in one and rectosigmoid junction in the second.

According to the World Health Organization (WHO) classification, B cell lymphomas are classified into diffuse large B cell lymphoma, extranodal marginal zone lymphoma (mucosa-associated lymphoid tissue [MAL$\mathrm{T}]$-associated lymphoma), mantle cell lymphoma (MCL), Burkitt's lymphoma, and follicular lymphoma [8]. Diffuse large cell B lymphoma (DLBCL) is the most frequent histological subtype affecting the gastrointestinal tract and colon [9]. DLBCL are composed of rapidly proliferating cells and are more aggressive than other B cell lymphomas.

Primary colorectal lymphoma mainly affects older age group in the fifth to seventh decade of life with male:female ratio being 1.5:1 [10]. Wong and $\mathrm{Eu}$ [11] in their study of 14 cases found mean age of presentation to be 61 years, whereas Bairey et al. [3] found it to be 72 years. In contrast to the above studies, our patient presented with lymphoma at 13 and 20 years of age probably the youngest reported case in the literature.

The presentation of B cell lymphoma is varied, and symptoms depend on the site of lesion. Most commonly, abdominal pain, weight loss, abdominal mass, and hematochezia, besides the features of obstruction like nausea, vomiting, change in bowel habits $[1,3]$, obstruction $[1$, $5]$, intussusceptions [12, 13], and acute peritonitis due to intestinal perforation $[1,3]$, are present. Fan et al. [10] in their series of 37 patients reported abdominal pain and weight loss in $62 \%$ and $43 \%$ of cases respectively, whereas Bairey et al. [3] reported abdominal pain and weight loss respectively in $56 \%$ and $29 \%$ of cases. Intestinal

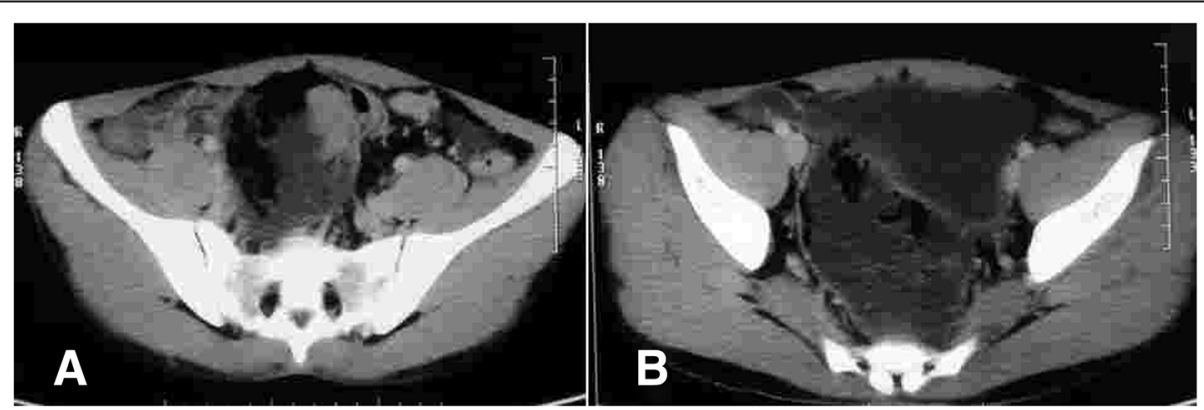

Fig. 3 Computed tomographic images showing a) tumor at rectosigmaoid junction b) lesion in upper rectum 


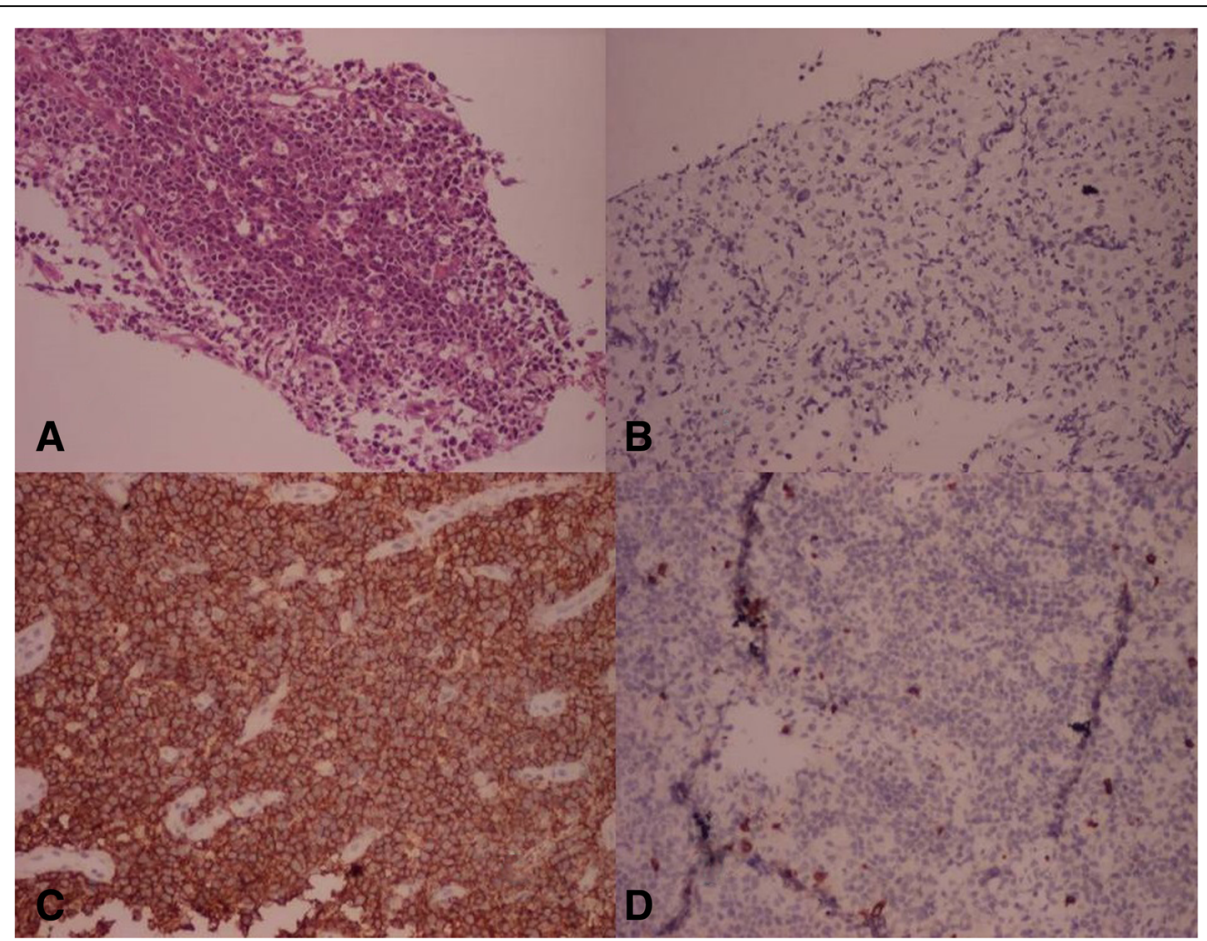

Fig. 4 Photomicrograph showing a sheets of monomorphic round cells having vesicular nuclei with distinct nucleoli H\&E $\times 10$, b cytokeratin negative, c CD20 positivity, and $\mathbf{d} C D 3$ negative

obstruction is a very rare presentation due to more pliable nature of colorectal lymphoma and the absence of desmoplastic response; however, symptoms of partial obstruction are more frequent. More than half of the patients present with bulky disease usually more than $5 \mathrm{~cm}[3,10,14]$. Surprisingly, in most cases of colonic B cell lymphoma reported in the literature, the B symptoms are often absent and fever is very rarely a presenting symptom. This is probably due to anatomical location wherein bowel-related symptoms appear first.

The most common imaging modalities used to image colonic lymphoma are contrast-enhanced computed tomography (CECT) of the abdomen or double contrast barium enema (DCBE), both of which complement each other. CECT abdomen provides extraluminal information like tumour size, depth of invasion, and regional nodal involvement, whereas DCBE provides more information about mucosal changes and gross tumour morphology. It is to be noted that both these modalities are not able to differentiate colonic carcinoma from lymphoma and diagnosis has to be confirmed by colonoscopy and biopsy. Immunohistochemistry are required for sub-classification. Full haematology including a peripheral smear, biochemistry, chest X-ray, CT scans, and bone marrow biopsy are required to rule out systemic involvement and for staging the disease. Though there is no consensus on what is ideal investigation for staging, evidence is slowly emerging to suggest usefulness of PET-CT for extranodal lymphoma as well.

The most widely used staging system in clinical practice is the Lugano classification which is based on Ann Arbor system modified by Carbone et al. [15]. Stage I is involvement of a single nodal group or single extranodal site (IE). Stage II comprises of involvement of more than one nodal group on the same side of the diaphragm or single extranodal site and adjacent lymph nodes (IIE). In stage III, there is involvement of multiple nodal sites on both sides of the diaphragm, including extranodal sites (IIIE) or spleen (IIIS). Stage IV is involvement of bone marrow, central nervous system, or diffuse visceral involvement.

The principal modality of treatment is combined modality treatment that includes surgery and chemotherapy [16]. Early stage tumours are treated with surgery followed by polychemotherapy, and advanced stage tumours are treated with multidrug chemotherapy $[1,3$, 17]. However, since the availability of rituximab, the CD20-positive B cell lymphomas can be treated with polychemotherapy combined with immunotherapy with complete and lasting response making the surgery redundant in these cases, as can be seen from the present case reports wherein surgery was avoided due to preoperative diagnosis and polychemoimmuno therapy.

Stage IE or IIE, disease confined to the colon or rectum with (IIE) or without (IE) regional lymph node 
Table 1 Published studies on colorectal lymphoma

\begin{tabular}{|c|c|c|c|c|}
\hline Author (year) [Ref.] & $\begin{array}{l}\text { Number } \\
\text { of cases }\end{array}$ & Histological type (WHO) & Treatment modality & Survival \\
\hline Bairey et al. 2006 [3] & 17 & $\begin{array}{l}\text { Diffuse large B cell } \\
\text { lymphoma }\end{array}$ & $\begin{array}{l}\text { Multimodality, } 9 \\
\text { Chemotherapy, } 6 \\
\text { Surgery, } 2\end{array}$ & Median, 44 months \\
\hline Musallam et al. 2010 [26] & 9 & $\begin{array}{l}\text { Diffuse large B cell } \\
\text { lymphoma, } 6 \\
\text { Burkitt lymphoma, } 3\end{array}$ & $\begin{array}{l}\text { Multimodality, } 5 \\
\text { Chemotherapy, } 3 \\
\text { Surgery, } 1\end{array}$ & Median, 25 months \\
\hline Wong and Eu 2006 [11] & 14 & $\begin{array}{l}\text { Diffuse large B cell } \\
\text { lymphoma }\end{array}$ & $\begin{array}{l}\text { Multimodality, } 11 \\
\text { Surgery, } 3\end{array}$ & 5-year overall survival, 57\% \\
\hline Kim et al. 2005 [27] & 95 & $\begin{array}{l}\text { B cell, } 82.1 \% \\
\text { T cell, } 17.9 \%\end{array}$ & $\begin{array}{l}\text { Multimodality, } 57 \\
\text { Chemotherapy, } 23 \\
\text { Surgery, } 15\end{array}$ & 5-year overall survival, 55.2\% \\
\hline Pandey et al. 2002 [28] & 8 & $\begin{array}{l}\text { Large cell, } 3 \\
\text { Small cell, } 1 \\
\text { Mix large and small, } 3 \\
\text { Lymphoblastic, } 1\end{array}$ & $\begin{array}{l}\text { Surgery with adjuvant } \\
\text { therapy in all }\end{array}$ & $66 \% 4$ years \\
\hline Auger et al. 1990 [29] & 22 & $\begin{array}{l}\text { Diffuse histiocytic } \\
\text { lymphoma }\end{array}$ & $\begin{array}{l}\text { Multimodality, } 14 \\
\text { Surgery, } 8\end{array}$ & N/A \\
\hline Zighelboim and Larson 1994 [30] & 15 & & $\begin{array}{l}\text { Multimodality, } 3 \\
\text { Chemotherapy, } 12\end{array}$ & 5-year survival, $27 \%$ \\
\hline Gonzalez et al. 2008 [5] & 15 & & $\begin{array}{l}\text { Multimodality, } 12 \\
\text { Surgery, } 3\end{array}$ & Median survival, 60 months \\
\hline Doolabh et al. 2000 [2] & 7 & $\begin{array}{l}\text { Small non-cleaved, } 5 \\
\text { Large cell, } 2\end{array}$ & $\begin{array}{l}\text { Multimodality, } 6 \\
\text { Surgery, } 1\end{array}$ & N/A \\
\hline Cho et al. 1997 [31] & 23 & & $\begin{array}{l}\text { Multimodality, } 14 \\
\text { Chemotherapy, } 4 \\
\text { Surgery, } 3\end{array}$ & 10-year survival, 61\% \\
\hline Fan et al. 2000 [10] & 37 & $\begin{array}{l}\text { High grade, } 29 \\
\text { Intermediate and low } \\
\text { grade, } 8\end{array}$ & $\begin{array}{l}\text { Multimodality, } 22 \\
\text { Chemotherapy, } 2 \\
\text { Surgery, } 13\end{array}$ & Median survival, 24 months \\
\hline Stanojevic et al. 2008 [14] & 24 & & $\begin{array}{l}\text { Multimodality, } 20 \\
\text { Surgery, } 4\end{array}$ & Median survival, 41.9\% \\
\hline Busch et al. 1994 [32] & 19 & & $\begin{array}{l}\text { Multimodality, } 14 \\
\text { Chemotherapy, } 4 \\
\text { Surgery, } 1\end{array}$ & Median survival, 45 months \\
\hline Zinzani et al. 1997 [1] & 32 & $\begin{array}{l}\text { High grade, } 26 \\
\text { Low grade, } 6\end{array}$ & $\begin{array}{l}\text { Multimodality, } 22 \\
\text { Chemotherapy, } 10\end{array}$ & 5-year overall survival, 59\% \\
\hline Zhou et al. 2011 [25] & 32 & $\begin{array}{l}\text { B cell, } 22 \\
\text { (DLBCL most common) } \\
\text { T cell, } 10\end{array}$ & $\begin{array}{l}\text { B cell, multimodality (22) } \\
\text { T cell, surgery (8) }\end{array}$ & $\begin{array}{l}\text { B cell DFS at } 55 \text { months, } \\
88.2 \% \\
\text { T cell, } 3 \text { alive after } \\
23 \text { months }\end{array}$ \\
\hline She et al. 2011 [33] & 10 & $\begin{array}{l}\text { B cell, } 8 \\
\text { Burkitt, } 1 \\
\text { Mantle cell, } 1\end{array}$ & $\begin{array}{l}\text { Surgery, } 7 \\
\text { Chemotherapy, } 3\end{array}$ & $\begin{array}{l}\text { Median survival } \\
\text { Surgery, } 17 \text { months } \\
\text { Chemotherapy, } 13 \text { months }\end{array}$ \\
\hline Zhai et al. 2012 [22] & 46 & $\begin{array}{l}\text { B cell origin, } 35 \\
\text { T cell, } 11\end{array}$ & & $\begin{array}{l}\text { 5-year survival, } 64.2 \% \\
\text { Progression-free survival, } \\
49.3 \%\end{array}$ \\
\hline Pascual et al. 2013 [34] & 7 & $\begin{array}{l}\text { Diffuse large B cell } \\
\text { lymphoma, } 6 \\
\text { Follicular lymphoma, } 1\end{array}$ & $\begin{array}{l}\text { Multimodality, } 2 \\
\text { Chemotherapy, } 2 \\
\text { Surgery, } 3\end{array}$ & N/A \\
\hline Huang et al. 2013 [35] & 52 & $\begin{array}{l}\text { Diffuse large B cell } \\
\text { lymphoma, } 64.4 \%\end{array}$ & $\begin{array}{l}\text { Multimodality, } 43 \\
\text { Chemotherapy, } 9\end{array}$ & 5-year survival, 71\% \\
\hline Tevlin et al. 2015 [36] & 11 & $\begin{array}{l}\text { Diffuse large B cell } \\
\text { lymphoma }\end{array}$ & $\begin{array}{l}\text { Multimodality, } 9 \\
\text { Chemotherapy, } 1 \\
\text { Radiotherapy alone, } 1\end{array}$ & $\begin{array}{l}\text { Median event-free survival, } \\
10 \text { months }\end{array}$ \\
\hline
\end{tabular}


involvement, had been treated with surgery followed by adjuvant chemotherapy [18]. In most series of published literature, surgery was followed by adjuvant multiagent chemotherapy (CHOP) which has led to improved outcomes [2, 18, 19]. Adjuvant chemotherapy has been shown to improve median survival from 36 to 53 months in a series of 15 patients (out of which 8 received adjuvant therapy) [20]. Similarly, Fan et al. [10] reported an improvement in median survival from 24 to 36 months. Aviles et al. [19] reported 83\% 10-year overall survival in patients with stage IE treated with surgery followed by adjuvant chemotherapy. However, other studies found surgical resection of localised, primary colonic lymphoma to provide excellent local disease control $[2,5]$. One of the reasons for avoiding primary chemotherapy is the fear of perforation of the bowel.

Surgery is the prime mode of therapy for palliation of pain and emergent conditions like obstruction, perforation, and bleeding. In a series of 43 patients reported by Cai et al. [21], 56\% of the patients required emergency operation. Similarly, in a case series of 46 patients by Zhai et al. [22], 13 patients required emergency surgery.

Rapidly proliferating and aggressive advanced lymphoma is best treated with chemotherapy. The CHOP chemotherapeutic regimen (cyclophosphamide, doxorubicin, vincristine, and prednisone) is a mainstay of treatment for all moderate and high grade B cell lymphomas. Addition of rituximab to standard $\mathrm{CHOP}$ regimen has led to improvement of progression-free, event-free, disease-free, and overall survival [23]. With the advent of new monoclonal antibodies like rituximab, there is a shifting trend towards use of chemotherapy in all cases with surgery reserved mainly for palliation of emergent condition [24].

However, due to rarity of disease, no prospective randomised clinical trials have been designed yet to define the optimal therapy of primary colonic lymphoma. Treatment decisions mainly depend upon expert opinion and consensus made on the basis of level II/III and IV evidence that is in abundance (Table 1).

Prognosis is often mixed with median survival of above 5 years reported in various series. Fan et al. [10] found stage to be the most important prognostic factors for survival. Others found histological grade to be the most important prognostic factor [3, 14, 21]. Urgency of surgical operation has also been reported as an important factor affecting survival $[3,14]$ along with histological subtype wherein $\mathrm{B}$ cell lymphomas have better prognosis than $\mathrm{T}$ cell phenotype [22, 25].

\section{Conclusion}

Primary colonic lymphoma is a rare clinical entity presenting most commonly in older age group. The presentation is often nonspecific which leads to delayed diagnosis and advanced stage at presentation. Surgery followed by chemotherapy is the recommended treatment; however, in select cases, chemotherapy alone with inclusion of rituximab can be used. There is fear of perforation with use of systemic therapy, although in most series, chemotherapy-induced perforations have not been reported and fear appears to be unfounded. The reported prognosis of colonic lymphoma is poor and recurrences are common; however, with use of R-CHOP, improved survival is reported.

\section{Acknowledgements \\ None. \\ Funding \\ None. \\ Availability of data and materials \\ The data presented in this manuscript is available with authors. \\ Authors' contributions \\ MP conceived and designed the study and edited the final manuscript. JS collected the data, performed a literature review, and produced the draft manuscript. HMI and MS contributed to the pathological part of the review and helped with the writing of the manuscript. All authors read and approved the final manuscript.}

\section{Ethics approval and consent to participate}

Written informed consent was obtained from the patient and legal guardian for publication of these case reports.

\section{Consent for publication}

Written informed consent was obtained from the patient and legal guardian for publication of these case reports.

\section{Competing interests}

The authors declare that they have no competing interests.

\section{Publisher's Note}

Springer Nature remains neutral with regard to jurisdictional claims in published maps and institutional affiliations.

\section{Author details}

${ }^{1}$ Department of Surgical Oncology, Institute of Medical Sciences, Banaras Hindu University, Varanasi 221 005, India. ${ }^{2}$ Department of Histopathology, Lal Path Labs, New Delhi, India. ${ }^{3}$ Dharamsheela Cancer Centre, Delhi, India.

${ }^{4}$ Department of Pathology, SRL Lab, Varanasi, India.

Received: 1 October 2018 Accepted: 23 December 2018

Published online: 15 January 2019

\section{References}

1. Zinzani PL, Magagnoli M, Pagliani G, Bendandi M, Gherlinzoni F, Merla E, et al. Primary intestinal lymphoma: clinical and therapeutic features of 32 patients. Haematologica. 1997;82:305-8 [PubMed].

2. Doolabh N, Anthony T, Simmang C, Bieligk S, Lee E, Huber P, et al. Primary colonic lymphoma. J SurgOncol. 2000;74:257-62.

3. Bairey O, Ruchlemer R, Shpilberg O. Non-Hodgkin's lymphomas of the colon. Isr Med Assoc J. 2006;8:832-5.

4. Wong MT, Eu KW. Primary colorectal lymphomas. Color Dis. 2006;8: 586-91. PubMed.

5. Gonzalez QH, Heslin MJ, Davila-Cervantes A, Alvarez-Tostado J, de los Monteros AE, Shore G, et al. Primary colonic lymphoma. Am Surg. 2008;74:214-6. PubMed.

6. Zhang KR, Jia HM. Primary non-Hodgkin's lymphoma of the sigmoid colon in a child. Am J Surg. 2009;197:e11-2. PubMed.

7. Ladd AP, Grosfeld JL. Gastrointestinal tumors in children and adolescents. SeminPediatr Surg. 2006;15:37-47. PubMed. 
8. Harris NL, Jaffe ES, Diebold J, et al. Lymphoma classification — from controversy to consensus: the R.E.A.L. and WHO classification of lymphoid neoplasms. Ann Oncol. 2000;11(1):3-10 [PubMed].

9. Koch $P$, del Valle F, Berdel WE, et al. Primary gastrointestinal non-Hodgkin's lymphoma: I. Anatomic and histologic distribution, clinical features, and survival data of 371 patients registered in the German Multicenter Study GIT NHL 01/92. JClinOncol. 2001;19:3861-73. PubMed.

10. Fan CW, Changchien CR, Wang JY, et al. Primary colorectal lymphoma. Dis Colon Rectum. 2000;43:1277-82. PubMed.

11. Wong MT, Eu KW. Primary colorectal lymphomas. Color Dis. 2006;8(7):586-91.

12. Chiang JM, Lin YS. Tumor spectum of adult intussusception. J SurgOncol. 2008;98:444-7. PubMed.

13. Zubaidi A, Al-Saif F, Silverman R. Adult intussusception: a retrospective review. Dis Colon Rectum. 2006;49:1546-51.

14. Stanojević GZ, Stojanović MP, Stojanović MM, Krivokapić Z, Jovanović MM, Katić W, Jeremić MM, Branković BR. Non-Hodgkin's lymphomas of the large bowel-clinical characteristics, prognostic factors and survival. ActaChirlugosl. 2008;55:109-14.

15. Carbone PP, Kaplan HS, Musshoff K, et al. Report of the committee on Hodgkin's disease staging classification. Cancer Res. 1971;31:1860-1.

16. Tondini C, Giardini R, Bozzetti F, Valagussa P, Santoro A, Bertulli R, et al. Combined modality treatment for primary gastrointestinal nonHodgkin's lymphoma: the Milan cancer Institute experience. AnnOncol. 1993;4:831-7. PubMed.

17. Dalal L. Primary multifocal non-Hodgkin's lymphoma of the colon successfully treated with chemotherapy. GastrointestEndosc. 2008;68: 1005-6 discussion 1006. [PubMed].

18. Waisberg J, Bromberg SH, Franco MI, Matheus CO, Zanotto A, Petrolino LF, Beltrami AM, Godoy AC. Primary non-Hodgkin lymphoma of the right colon: a retrospective clinical-pathological study. Int Surg. 2001;86(1):20-5.

19. Avilés A, Neri N, Huerta-Guzmán J. Large bowel lymphoma: an analysis of prognostic factors and therapy in 53 patients. J Surg Oncol. 2002 Jun;80(2):111-5

20. Zighelboim J, Larson MV. Primary colonic lymphoma. Clinical presentation, histopathologic features, and outcome with combination chemotherapy. J Clin Gastroenterol. 1994;18:291-7.

21. Cai S, Cannizzo F Jr, Bullard Dunn KM, Gibbs JF, CzuczmanM RA. The role of surgical intervention in non-Hodgkin's lymphoma of the colon and rectum. Am J Surg. 2007;193:409-12 discussion 412.

22. Zhai L, Zhao Y, Lin L, Tian Y, Chen X, Huang H, Lin T. Non-Hodgkin's lymphoma involving the ileocecal region: a single-institution analysis of 46 cases in a Chinese population. J Clin Gastroenterol. 2012;46(6):50914. https://doi.org/10.1097/MCG.0b013e31823716c.

23. Morrison VA. Evolution of R-CHOP therapy for older patients with diffuse large B-cell lymphoma. Expert Rev Anticancer Ther. 2008;8:1651-8.

24. Salar A, Domingo-Domenech E, Estany C, Canales MA, Gallardo F, Servitje $\mathrm{O}$, et al. Combination therapy with rituximab and intravenous or oral fludarabine in the first-line, systemic treatment of patients with extranodal marginal zone B-cell lymphoma of the mucosa-associated lymphoid tissue type. Cancer. 2009;115:5210-7.

25. Zhou JL, Qiu HZ, Sun J, Li J. The diagnosis and treatment of colorectal nonHodgkin's lymphoma 32 cases. Zhonghua Wai Ke Za Zhi. 2011;49(4):290-4.

26. Musallam KM, Hatoum HA, Barada K, Taher AT, Salem ME, Malek EM, Shamseddine Al. Primary colorectal lymphoma. Med Oncol. 2010;27(2):24954. https://doi.org/10.1007/s12032-009-9200-5 Epub 2009 Mar 20.

27. Kim YH, Lee JH, Yang SK, Kim TI, Kim JS, Kim HJ, Kim JI, Kim SW, Kim JO, Jung IK, Jung SA, Jung MK, Kim HS, Myung SJ, Kim WH, Rhee JC, Choi KY, Song IS, Hyun JH, Min YI. Primary colon lymphoma in Korea: a KASID (Korean Association for the Study of Intestinal Diseases) study. Dig Dis Sci. 2005;50(12):2243-7.

28. Pandey M, Wadhwa MK, Patel DD, Kothari KC. Primary malignant large bowel lymphoma. Am Surg. 2002;68:121-6.

29. Auger MJ, Allan NC. Primary ileocecal lymphoma: a study of 22 patients. Cancer. 1990;65:358-61.

30. Zighelboim J, Larson MV. Primary colonic lymphoma: clinical presentation, histopathologic features, and outcome with combination chemotherapy. J Clin Gastroenterol. 1994;18:291-7.

31. Cho MJ, Ha CS, Allen PK, Fuller LM, Cabanillas F, Cox JD. Primary non-Hodgkin lymphoma of the large bowel. Radiology. 1997;205:535-9.

32. Busch E, Rodriguez-Bigas M, Mamounas E, Barcos M, Petrelli NJ. Primary colorectal non-Hodgkin's lymphoma. Ann Surg Oncol. 1994;1:222-8.
33. She WH, Day W, Lau PY, Mak KL, Yip AW. Primary colorectal lymphoma: case series and literature review. Asian J Surg. 2011;34(3):111-4. https://doi.org/ 10.1016/j.asjsur.2011.08.004 Epub 2011 Oct 22.

34. Pascual M, Sánchez-González B, García M, Pera M, Grande L. Primary lymphoma of the colon. Rev Esp Enferm Dig. 2013;105:74-8 doi: 10.4321.

35. Huang S, Zheng ZX, Xu Q, Yuan XH. Diagnosis and treatment of primary colorectal non-Hodgkin's lymphoma: analysis of 52 cases. Zhonghua Zhong Liu Za Zhi. 2013;35(4):305-8.

36. Tevlin R, Larkin JO, Hyland JM, O'Connell PR, Winter DC 2: Primary colorectal lymphoma - a single centre experience. Surgeon. 2015;13(3):151-155. https://doi.org/10.1016/j.surge.2014.01.002. Epub 2014 Mar 30.

\section{Ready to submit your research? Choose BMC and benefit from:}

- fast, convenient online submission

- thorough peer review by experienced researchers in your field

- rapid publication on acceptance

- support for research data, including large and complex data types

- gold Open Access which fosters wider collaboration and increased citations

- maximum visibility for your research: over $100 \mathrm{M}$ website views per year

At BMC, research is always in progress.

Learn more biomedcentral.com/submissions 